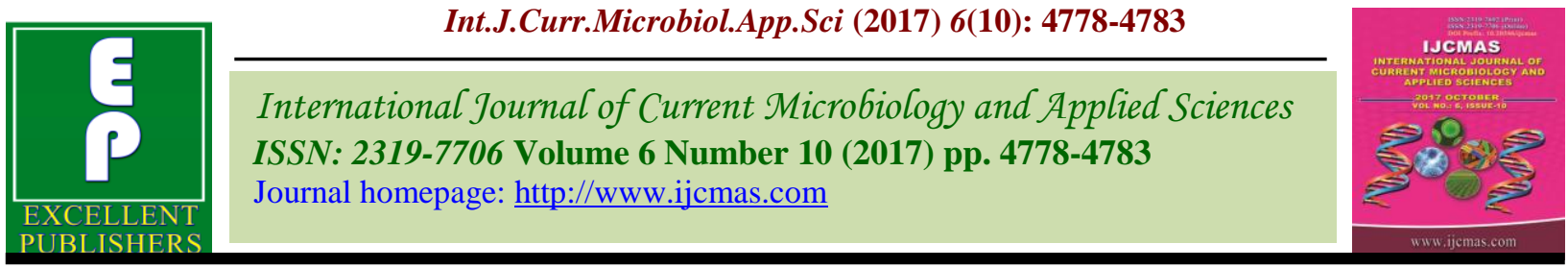

Review Article

https://doi.org/10.20546/ijcmas.2017.610.444

\title{
Hybrid Napier for Round the Year Quality Fodder Supply to the Dairy Industry- A Review
}

\author{
S.S. Kadam ${ }^{1 *}$, Ashok Kumar ${ }^{2}$ and Mohd. Arif ${ }^{3}$ \\ ${ }^{1}$ Fodder Development Officer, Bombay Veterinary College, \\ Mumbai- 400012, Maharashtra, India \\ ${ }^{2}$ ICAR-NBSS \& LUP, Regional Centre, New Delhi-110012, India \\ ${ }^{3}$ Agronomy, Rajasthan College of Agriculture, MPUAT, Udaipur-313001, India \\ *Corresponding author
}

\section{Keywords \\ Dairy farming, \\ Farmers, Crop, Quality.}

Article Info

Accepted:

29 September 2017

Available Online:

10 October 2017

\section{A B S T R A C T}

The dairy farming in India is becoming independent and economically viable enterprise that provides quick and regular income to the farmers from the sale of milk and its byproducts. Beside, supplementing income of the farmers it also supports the livelihood in the event of crop failures, often occurred due to aberrant weather situation. However, success of dairy farming mainly depends on feed and fodder of good quality. Unfortunately, there is shortage of quality fodder in India due to less area under cultivation. The animals are largely fed on inferior quality fodders such as crop residues, straw, weeds and wild grasses from wastelands and forest. Such low quality feeding material leads to low milk productivity per animal. This situation needs to be addressed through alternative sources of fodder which could provide good quality fodder round the year so that the milk productivity as well as animal health may not jeopardised. In terms of quality and availability of good quality fodder hybrid napier proved to be a better option under Indian conditions because of its perennial nature, profuse tillering habit, high yield, palatability, nutritional value and suitability for silage making than other forage crops. Hybrid napier grass may be a boon for dairy industry on account of supply of adequate green fodder of high nutritional value with round the year availability and minimum expense on repeated fodder cultivation.

\section{Introduction}

Agriculture is facing several challenges such as frequent occurrence of droughts and floods, declining land holding size and degradation of natural resources. Under these situations farming alone may be a risky enterprise. Hence, dairy farming may be a support to agriculture to reduce the risk of crop failure. However, success of dairy farming is largely depends on the feed and fodder of high nutritional value, which accounts for 65-70 per cent expenses incurred over the animal feeds (Kumar et al., 2012). Fodder is cheap source of nutrient supply than concentrate feed and needs to given more emphasis so as to make the dairy industry economically viable option. In India limited land (8.6 m ha) is available for fodder cultivation (Kumar et $a l$., 2012) and our country may face the shortage of both green as well as dry fodder by about 61.1 and 21.95, respectively (IGFRI, 
2011). This forced majority of the farmers to feed their animals on poor quality crop residue or wild grasses (Hegde, 2012). Aher et al., (2003) reported that about $97 \%$ of available fodder is of very poor quality, which along with inadequate availability causes decline in animal health and milk productivity. Despite the fact that India ranks first in milk production in the world (The Economic survey, 2016-17), per animal milk productivity remained very low $(<1000$ litre $)$ compare to United States of America (4500 litre), Europe (7000 litre) to as high as 10,000 litres per animal per lactation in Israel (DARE, 2013). The performance of the animals depends on the quantity and quality as well as availability of green fodder at various times during the year (Hatam et al., 2001). Forage crops such as maize, sorghum, oat, barley, cowpea and berseem crops are palatable and nutritious but seasonal in nature due to this there is scarcity of fodder during the remaining period of year. Besides, it also requires frequent expenses for repeated tillage operations which add to the total cost of cultivation. February and Higgins (2010) reported that grasses are advantageous than other plant species due to their adaptation and acclimatization to climate and soil.

Hybrid napier is also known as Bajra-Napier hybrid, Napier Bajra hybrids, King grass, Elephant millet, Cumbu-napier hybrid. It is widely distributed in tropical and sub-tropical regions of Asia, Africa, southern Europe and India. It is tall growing $(200-300 \mathrm{~cm})$, erect, stout, deep rooted, perennial grass derived from inter specific cross between Pennisetum glaucum and $P$. purpureum. The hybrid is a triploid and hence sterile do not produce seed. Pandey and Roy (2011) reported that among the improved fodder grass species, hybrid napier is multicut perennial grass with profuse tillering and very good tonnage throughout year. It can be grown saline soils, wastelands, bund and terraces. It grows well under arid and semi-arid region of India. Singh et al., (2002) reported that it is very popular among the farmers due to its high yielding capacity, palatability, nutritive value and suitability to varying climatic and soil conditions. Besides, it also supplies green fodder at least for five years once established (Rahman and Talukder, 2015). Hybrid napier produces silage with pleasant aroma (Kung and Shaver, 2002) and of good quality due to production of lactic acid, acetic acid and butyric acid during the fermentation process (Miyagi et. al, 1993). The silage prepared from hybrid napier may be utilized during off season to mitigate the fodder scarcity. The available reviews indicated that the scientifically well managed hybrid napier grass could be a good alternative for sustained green forage supply round the year, of high quality to fulfil the nutritious fodder requirement of the dairy animals.

\section{Agronomic practices for better quality and fodder yield of Hybrid Napier}

\section{Selection of suitable variety}

Selection of variety is important to achieve high yield per unit area under various soils and agro-climatic conditions. Das et al., (2000) reported that among different hybrid grass varieties, KKM-1 is more suitable under irrigated condition. Tiwana et al., (2004) observed that hybrid napier variety $\mathrm{PBN}-233$ produced higher green fodder and dry matter yield. Hybrid napier variety $\mathrm{CO}-3$ produced highest green forage and dry matter yield under different locations (Premaratne and Premalal, 2006; Chellamuthu et al., 2011; Raj and palled, 2014).

\section{Nutritional quality of Hybrid Napier}

Antony and George (2014) recorded that nutritional parameters viz., crude protein, crude fibre, total ash and mineral content 
differ significantly under different cultivars of Hybrid Napier. Sarmini and Premratne (2017) reported that hybrid napier produced significantly higher dry matter $(17 \%)$, ether extract $(4.34 \%)$ and ash $(16.06 \%)$ content compare to sorghum. It also produced significantly high crude protein $(10.92 \%)$ as compare to maize $(7.35 \%)$. Hybrid napier is quantitatively as well as qualitatively superior over other perennial grasses. Senthil et.al, (2016) reported that hybrid napier contains low ADF and NDF indicating low fibre and more digestibility for livestock. Kadam et al., (2016) from Goregaon (Maharashtra) reported that hybrid napier varieties viz. $\mathrm{CO}-4, \mathrm{DHN}-6$ and $\mathrm{CO}-3$ produces high crude protein content (11.36,10.63 and $9.86 \%$, respectively) under heavy rainfall conditions.

\section{Planting of hybrid napier}

Pandey and Roy (2011) observed that root slips or stem-cuttings yield better if planted at a distance of $60 \times 90 \mathrm{~cm}, 90 \times 90 \mathrm{~cm}$ or $90 \times$ $120 \mathrm{~cm}$ depending on the soil status. Jayanthi (2003) reported that hybrid napier variety CO-3 planted on furrow and buried in soil gave the highest green fodder yield.

\section{Fertilizers and nutrient management}

Walmsley et al., (1978) reported that on an average hybrid napier grass removes 463:96:594 $\mathrm{Kg} \mathrm{ha}^{-1}$ nitrogen, phosphorus and potassium, respectively. Malarvizhi and Rajamannar (2001) reported that crop should be supplied with recommended doses of manure and fertilizer to sustain crop yield and nutrients replenishment. Jayanthi (2003) reported that higher yield of hybrid napier grass could be achieved with adequate organic manure. Sidhy (2003) reported that application of $20 \mathrm{t} \mathrm{ha}^{-1}$ farm yard manure before planting of hybrid napier proved beneficial to increase overall forage production. Application of $75 \quad \mathrm{Kg}$ nitrogen/ha/cut increased the fodder yield of Napier Bajra hybrid significantly (Tiwana et al., 2004). Pathan and Bhilare (2009) found that application of 62.50:50:25 $\mathrm{kg} \mathrm{ha}^{-1}$ NPK and $25 \mathrm{~kg} \mathrm{ha}^{-1} \mathrm{~N}$ after each cut produced higher green forage yield and dry mater yield. Raj and Palled (2014) reported that hybrid napier variety $\mathrm{CO}-3$ recorded significantly higher green fodder, dry matter and crude protein yield when supplied with $300 \mathrm{Kg} \mathrm{N}$ $\mathrm{ha}^{-1}$

Table.1 Yield of hybrid napier genotypes under various zones in India (Adopted from Pandey and Roy, 2011)

\begin{tabular}{|l|l|c|}
\hline Genotype & Area recommended for cultivation & Green forage yield (t ha $^{-1}$ ) \\
\hline CO 1 & South Zone & 300 \\
\hline Hybrid Napier 3 (Swetika) & North and Central Zone & $70-80$ \\
\hline NB 21 & Whole of India and tropics & $100-160$ \\
\hline Yeshwant (RBN 9) & Maharashtra & 150 \\
\hline PBN 83 & Punjab & $125-170$ \\
\hline Pusa Giant napier & Whole of India and tropics & 350 \\
\hline CO 2 & South zone & $130-200$ \\
\hline CO-3 & South Zone & 250 \\
\hline KKM 1 & South districts of Tamil Nadu & 200 \\
\hline APBN 1 & Andhra Pradesh, Karnataka and Tamil Nadu & 375 \\
\hline PBN-233 & Punjab & 260 \\
\hline Saguna & South district of Kerala & $120-150$ \\
\hline Sampoorna (DHN-6) & Karnataka & \\
\hline
\end{tabular}




\section{Harvesting or cutting management}

Hybrid napier being a perennial forage grass, its cutting at right stage is an important aspect to obtain better quality as well as yield. Wangchuk et al., (2015) reported that total dry matter plant $^{-1}$ was higher at 80 days cutting interval compare to 40 days but reverse was the case with crude protein content. Besides, cutting interval significantly affects the total dry matter, plant height, number of tillers, leaves, and crude protein content plant ${ }^{-1}$.

\section{Hybrid napier as a better option for high yield and fodder availability}

Green forages become available in plenty during rainy season and become scarce after rainy season, which affects the health and productivity of animals. In such situation, silage is the better alternative to preserve and supply the green fodder during the period of shortage of green fodder. Hybrid napier is best alternative to supply adequate fodder for the animals round the year because of its perennial nature. Delena and Fulpagare (2015) reported that good quality silage can be prepared from hybrid napier. Biradar et al., (2014) reported green fodder yield of different hybrid napier varieties and found to high in case of DHN-6 (710 q ha).

Success of dairy industry depends upon the availability and supply quality fodder to the livestock. Since, most of the fodder crops are season bound and hence supply the fodder only to that particular season of the year and rest of the time animals faces acute shortage of green fodder of good quality. Under such conditions some alternate has to be developed so as to mitigate the fodder scarcity. In this context, hybrid napier could prove a better option due to its perennial nature and capacity to produce adequate green fodder round the year. This is being hardy in nature can withstand drought condition and can grow under varying soils and agro climatic regions. It provides sustained fodder yields for four to five years thus save frequent expenses on repeated tillage and sowing operations. Hybrid Napier is resourceful forage grass due to its perennial nature, high yielding ability, nutritional quality, palatability, suitability for silage making and low oxalate content than any other grasses. The excess green fodder yield of hybrid napier can be preserved as silage for mitigating the acute shortage of green fodder during lean season. Besides, it produces more nutritious fodder with good palatability, taste and succulence, which is relished by the animals. Hence, it fulfils the nutritional needs of the animals, reduces expenditure on feed procurement, increases the milk productivity and hence, makes the dairy farming more feasible and profitable.

\section{References}

Aher, V.B., Tambe, A.B., Manjare, M.R. and Desale, J.S. 2003. Forage Research in Maharashtra. Book Published by Forage Research Project, M.P.K.V. Rahuri (MS).p.1.

Antony, S., and George, T. C. 2014. Nutritive quality of hybrid napier cultivars grown under rainfed system. Journal of Tropical Agriculture 52 (1): 90-93.

Biradar, S.A., Shreedhar, J. N. and Ubhale, P. 2014. Economics and varietal performance of Hybrid napier and guinea grass under irrigated conditions of northern Karnataka. Forage Research 40 (2):95-97.

Chellamuthu, V., Saravanane, P. and George Paradis., 2011. Evaluation of bajranapier hybrid grass cultivars under coastal ecosystem of Karaikal, Puducherry Union Territory. Madras Agricultural Journal 98 (7-9): 253-254.

DARE, 2013. Department of Agricultural Research and Education, Ministry of 
Agriculture, Government of India. DARE Report (January-March).

Das, V., Thirumeni, L. D., Kandasamy, S., Rajaravindran, G. and Vivekanandan, P. 2000. KKM 1: A new high yielding cumbu napier hybrid grass for southern districts of Tamil Nadu. Madras Agricultural Journal 87(10-12): 632634.

Delena, M. F., and Fulpagare, Y.G. 2015. Characteristics of Silage Prepared from Hybrid Napier, Maize and Lucerne. IOSR Journal of Agriculture and Veterinary Science 8 (5):13-16.

Economic survey, 2016-17. Ministry of finance, GOI, New Delhi.

February, E. C., and Higgins, S.I. 2010. The distribution of tree and grass roots in savannas in relation to soil nitrogen and water. South African Journal of Botany 76: $517-52$.

Hatam, M., Akmal, M., Habib, G. and Siddiqui, M. 2001. Status paper on establishment of fodder and forage discipline. NWFP Agriculture University Peshawar. Pp.105.

Hegde, N.G., 2012. Combating drought in western region. The BAIF Journal 33: 7-9

IGFRI, 2011. Vision-2030, Indain Grassland and Forage Research Institute, Jhansi (UP). p.2.

Jayanthi, C., 2003. Productivity of BajraNapier hybrid grass under different planting methods and time of fertilizer applications.

htpp://www.tnau.ac.in/scms/agronomy/j ayanthi.htm.

Kadam, S.S., Baig, M. I., Karambale, N.R., and Kodape, A. H. 2016. Comparative performance of different varieties of hybrid napier and other perennial grasses under heavy rainfall region. Progressive Research - An International Journal 11(2):1054-1055. Kumar, S., Agrawal, R. K., Dixit, A. K., Rai,
A. K., Singh, J. B and Rai, S.K. 2012. Forage production technology for arable lands. Indian Grassland and Fodder Research Institute, Jhansi-284003. p.1.

Kung, L., and Shaver, R. 2002. Interpretation and use of silage fermentation analyses reports. Department of animal and food science, University of Delaware Newark, DE 19717.

Malarvizhi, P., and Rajamannar, A. 2001. Efficient utilization of sewage water for improving the forage yield and quality of bajra-napier hybrid grass. Madras Agricultural Journal 88 (7-9): 477-482.

Miyagi, E. Y., Kawamoto, Z., Koja, Y. Masuda and I. Goto 1993. The effect of cutting interval on quality and palatability of Napier grass (pennisetum purparuem schum) silage. J. Japan. Grasil. Sci. 39:51-56

Pandey, K.C., and Roy, A. K. 2011. Forage crops varieties, IGFRI, Jhansi. pp. 2527.

Pathan, S. H., and Bhilare, R. L. 2009. Influence of varying spacing and fertilizer levels on yield performance of hybrid napier verities. Forage Research 34 (1): 60-61.

Premaratne, S., and Premalal, G.G.C. 2006. Hybrid napier (Pennisetum perpureum $x$ Pennisetum americarnum) Var. CO-3: A resourceful fodder grass for dairy development in Srilanka. The Journal of Agricultural Science 2 (1): 24-32.

Rahman, M. Z., and Talukder, M. A. I. 2015. Production and nutritional quality of high yielding fodders in the coastal areas for ruminants. The Agriculturist 13(1):1-8.

Raj, Vinay, D. J., and Palled, Y.B. 2014. Response of hybrid napier genotypes to nitrogen levels. Karnataka Journal of Agricultural Science 27 (1): 74-75.

Sarmini, M., and Premaratne, S. 2017. Yield and nutritional quality potential of three fodder grasses in the northern region of 
Sri Lanka. Tropical Agricultural Research 28(2): 175-182.

Senthil, M., Balusami, C. S., K. K., Jiji and Asif, M. M. 2016. Proximate composition, fibre fraction values of environmentally adapted fodder varieties in wayanad district, Kerala, India. International Journal of Science, Environment and Technology 5(5):2855-2860.

Sidhy, B.S., 2003. Fodder hybrid that need promotion. "The Tribune", Online Edition, Monday, April 7, 2003. http://www.tribuneindia.com/2003/2003 30407/agro.htm\#1

Singh, D., Singh, V. and Joshi, Y. P. 2002. Herbage yield and yield attributes of Napier bajra hybrid at different cuts as affected by cutting intervals and varying level of nitrogen. Forage Research 27:
267-272.

Tiwana, M. S., Puri, K. P., Tiwana, U. S. and Singh, A. 2004. Forage production potential of napier bajra hybrid varieties under different nitrogen levels. Forage Research 30 (2):83-85.

Walmsley, D., Sargeant, V. A. L. and Dookeran, M. 1978. Effect of fertilizers on growth and composition of elephant grass (Pennisetum purpureum) in Tobago, West Indies. Tropical Agriculture (Trinidad) 25: 329-334.

Wangchuk, K., Rai, K., Nirola, Harilal, Dendup, C., Thukten and Durba, M. 2015. Forage growth, yield and quality responses of Napier hybrid grass cultivars to three cutting intervals in the Himalayan foothills. Tropical Grasslands-Forrajes Tropicales 3: 142-150.

\section{How to cite this article:}

Kadam, S.S., Ashok Kumar and Mohd. Arif. 2017. Hybrid Napier for Round the Year Quality Fodder Supply to the Dairy Industry- A Review. Int.J.Curr.Microbiol.App.Sci. 6(10): 47784783. doi: https://doi.org/10.20546/ijcmas.2017.610.444 